\title{
Juvenile growth of provenances and open pollinated families of four Russian larch species (Larix Mill.) in Swedish field tests
}

\author{
By L. Karlman ${ }^{1), 2), *)}$, A. Fries ${ }^{3)}$, O. Martinsson ${ }^{2)}$ and J. Westin ${ }^{4)}$
}

(Received $17^{\text {th }}$ August 2010)

\begin{abstract}
Four Russian larch species; (Larix sukaczewii Dyl., L. sibirica Ledeb., L. gmelinii Rupr. and L. cajanderi Mayr.) were tested in combined provenance-progeny tests on three sites in Sweden. 29 provenances, two seed orchards and four seed stands-material were assessed for juvenile height growth and survival after five growing seasons in the field. Genetic parameters were also determined on the family level. The results show that provenances of $L$. sukaczewii originating from western Russia have the highest survival. Compared to the closely related $L$. sibirica, L. sukaczewii show better adaptation, a pattern that has also been observed in Finland and Iceland. Provenances of $L$. gmelinii from the Russian Far East demonstrate best juvenile height growth on all three sites. L. cajanderi from northern interior Siberia failed on all three sites. Both climatic and geographical variables showed strong correlation with survival and height. At this early evaluation it seems like provenances of $L$. sukaczewii can be transferred northward with satisfactory survival whereas southern transfer or transfer from strongly continental areas in Russia to the semi maritime climate in Sweden results in poor growth. $\mathrm{CV}_{\mathrm{A}}$ values suggested relatively high genetic variation in height for $L$. sukaczewii and L. sibirica. The heritabilities for height growth and survival were at this early evaluation generally low $\left(\mathrm{h}^{2}<0.10\right)$ and often non-significant.
\end{abstract}

Key words: Larix sukaczewii, L. gmelinii, L. sibirica, L. cajanderi, provenance trials, half-sib families, heritability, height growth, genetic variation, climatic change.

\section{Introduction}

The international research on genetics and breeding of larch has focused on European larch (Larix decidua Mill.), Japanese larch (L. kaempferi Lamb.), hybrid larch (Larix x eurolepis Henry), and American western larch (L. occidentalis). However, larches (Larix Mill.) have their greatest area of distribution in Russia, cover-

\footnotetext{
1) Department of Forest Ecology and Management, Swedish University of Agricultural Sciences, SE-901 83 Umeå, Sweden. E-mail: lars.karlman@gmail.com.

2) Jämtlands Institute for Rural Development, Bispgården, Sweden. E-mail: Owe.Martinsson@ragunda.se.

3) Department of Forest Genetics and Plant Physiology, Swedish University of Agricultural Sciences, SE-90183 Umeå, Sweden. E-mail: Anders.Fries@genfys.slu.se.

4) Skogforsk (The Forestry Research Institute of Sweden), Box 3, SE-91821, Sävar, Sweden. E-mail: Johan.Westin@skogforsk.se.

*) Corresponding author: LARS KARLMAN. Department of Ecology and Management, Swedish University of Agricultural Sciences, S-90183 Umeå, Sweden and Jämtlands Institute for Rural Development, Bispgården, Sweden. Phone +46 696 30159, Fax +46696 30158. E-mail: lars.karlman@gmail.com.
}

ing an area of roughly 280 million hectares (37 percent of the forested land of Russia) stretching from the White Sea in northwestern Russia to Kamchatka in the East (Shvidenko and Nilsson, 1994). In European Russia, the distribution of larch is scattered and sparse, and larches constitute less than one percent of total growing stock in this area. In the Ural mountains and east of the Ural, larch representation increases, and east of the Jenisey river larch becomes the dominant tree species. In Siberia, $54 \%$ of the forests are dominated by larch (MARTINSSON and Lesinski, 2007). Taxonomists use different divisions of the Russian larches. At least two main species, Siberian larch (Larix sibirica Ledeb.) and Dahurian larch (L. gmelinii Rupr.) are identified, but there are several sub-species and natural hybrids of larch (Dylis, 1947). Thus, BoBRov (1972) separates L. cajanderi Mayr. from L. gmelinii and DYLIS (1981) suggests that L. sukaczewii Dylis., which has a western distribution, should be distinguished from $L$. sibirica. Phylogenetic studies by BASHALKANOV et al. (2003) and KHATAB et al. (2008) are in agreement with DyLIs (1981) and we therefore treat $L$. cajanderi and $L$. sukaczewii as separate species from $L$. gmelinii and $L$. sibirica, respectively. Consequently, the present paper makes separate analyses for the four species Larix sukaczewii, L. sibirica, L. gmelinii and L. cajanderi (Fig. 1).

Although Siberian larch now is treated as an indigenous species of Sweden, larch was absent from Scandinavia for a long period. The status as a non-exotic species was gained after findings of macro fossils of larch wood and cones, dated between 8700 and 7500 years BP, in Jämtland and Västerbotten in the Swedish mountains (KULLMAN, 1998). Later these findings have been confirmed by pollen records of Larix in Swedish Lapland during the Early Holocene era (BERGMAN et al., 2004). Thus, after the last ice age larch was one of the first colonizers in the Scandinavian mountains but disappeared for unknown reasons already in pre historic time. Larch was reintroduced into Scandinavia in the $18^{\text {th }}$ century. First European larch (Larix decidua) was introduced, and then about 50 years later Russian larch, mostly from the Arkhangelsk area, that is, L. sukaczewii, was introduced. The main reason for the interest in larch was for the wood quality, specifically its mechanical strength and resistance to decay.

In northern Sweden, volume production of $L$. sukaczewii is estimated to be $10-25 \%$ higher than in Scots pine over a rotation period of 100 years on medium or better sites (MARTINSSON, 1995). On poor sites the yield of larch is, however, inferior to Scots pine (EDLUND, 1966; Martinsson, 1995). Other features that make Siberian larch an interesting alternative are its shorter 


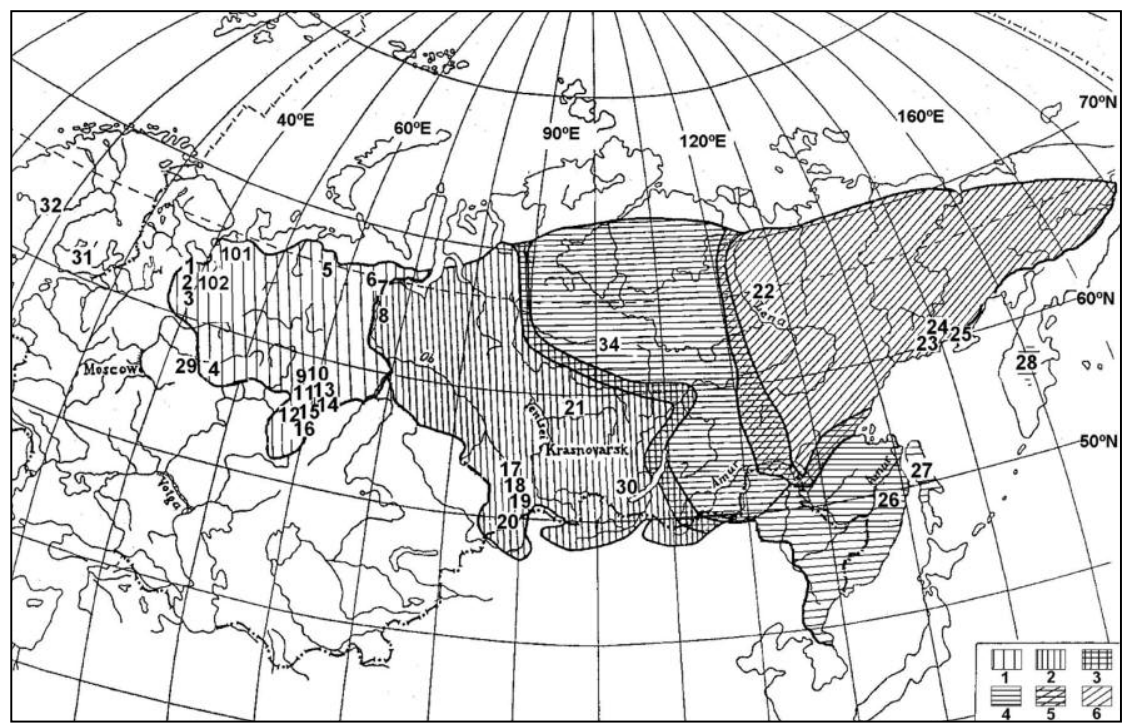

Figure 1. - Location of the provenances, stand collections and seed orchards as numbered in Table 2. No 33 Maglehem is not shown on the map. The six different patterns indicate larch species and their hybridization zones. $1=$ L. sukaczewii, $2=L$. sibirica, $4=$ L. gmelinii, $6=$ L. cajanderi. Hybridization zones: Area $3=L$. czekanovski ( $L$. sibirica $\times$ L. gmelinii), $5=L$. gmelinii $\times$ L. cajanderi . Map based on MiLYUTIN and VishnEVETSKAYA (1995) and modified according to SCHMidT (1995) and PUtenikHin and MARTINSSON (1995).

rotation periods and resistance to some diseases, namely Melampsora pinitorqua, Endocronartium pini, and Gremmeniella abietina, that have infected Scots pine, especially in northern Sweden (MARTINSSON and NILSSON, 1987; EIDMANN and KLINGSTRÖM, 1990; HANSSON et al., 2005).

Only a few seed sources have, however, been investigated, mainly Raivola seed source and L. sibirica from Krasnoyarsk. Before a more intensive use of larch in Sweden, the performance of different provenances of Russian larch species in different parts of the country needs to be evaluated. In the present paper, four larch species were evaluated by, in total, 1005 open pollinated half-sib families from 29 Russian provenances, three commercial Swedish and Finnish seed orchard crops and four Russian bulk stand collections (Table 2 and Fig. 1). In addition a Swedish seed orchard crop of $L$. x eurolepis was also tested. The evaluation was carried out in three combined provenance - half-sib progeny tests in north, central, and south Sweden (Table 1). The material is a considerable part of a collection of seeds made between 1996 and 2001 (ABAIMOV et al., 2002) for an international provenance and progeny test series. Earlier published results from these test series include ÖYEN et al. (2007), EYSTEINSSON et al. (2009) and LUKKARINEN et al. (2009).

The aims of the study were: $i$ ) to evaluate climatic adaptation and growth of the species in different environments in Sweden, ii) to evaluate potential transfer effects on survival and growth and iii) to evaluate the genetic variation in survival and height growth on provenance and family levels.

\section{Material and Methods}

The present study evaluates 29 Russian provenances (provenance Nos. 1-28 and 34). The seed material included 1005 half-sib families of Larix sukaczewii, L. sibirica, L. gmelinii and L. cajanderi collected within

Table 1. - Localities, climatic data and site properties for the three test sites. Öst = Österbymo; Sär = Särna and Jär = Järvträsk

\begin{tabular}{|c|c|c|c|c|c|c|c|c|c|c|}
\hline Site & Lat. N & Long. E & T-sum dd. ${ }^{1)}$ & Alt. $\mathrm{m}$ & MAT ${ }^{\circ} \mathbf{C}^{2}$ & $\mathrm{CI}^{3)}$ & $\mathbf{T C M}^{\circ} \mathbf{C}^{4)}$ & $A-M^{\circ} C^{5)}$ & Exp. & Soil \\
\hline Öst & $57^{\circ} 47^{\prime}$ & $15^{\circ} 37^{\prime}$ & 1160 & 250 & 5.8 & 21 & -3.4 & 6.8 & $\begin{array}{l}\text { Slight S } \\
\text { slope }\end{array}$ & $\begin{array}{l}\text { Gravelly } \\
\text { morain }\end{array}$ \\
\hline Sär & $61^{\circ} 31^{\prime}$ & $13^{\circ} 00^{\circ}$ & 725 & 540 & 0.8 & 29 & -11.5 & 3.2 & $\begin{array}{l}\text { Slight W } \\
\text { slope }\end{array}$ & $\begin{array}{l}\text { Stony } \\
\text { morain }\end{array}$ \\
\hline Jär & $65^{\circ} 11^{\prime}$ & $19^{\circ} 31^{\prime}$ & 650 & 410 & 0.1 & 34 & -13.4 & 2.6 & $\begin{array}{l}\text { Steep E } \\
\text { slope }\end{array}$ & $\begin{array}{l}\text { Sandy } \\
\text { morain }\end{array}$ \\
\hline
\end{tabular}

${ }^{1)}$ Temperature sum (degree days, dd.) based on Lindgren's temperature sum function (LINDGREN, 1994). ${ }^{2)}$ MAT $=$ Mean annual temperature. ${ }^{3)} \mathrm{CI}$. = continentality index. ${ }^{4)} \mathrm{TCM}=$ Mean temperature for coldest month and ${ }^{5)} \mathrm{A}-\mathrm{M}=\mathrm{Mean}$ temperatures for April and May. ${ }^{6)}$ Exp. = Exposition. 
Table 2. - Geographical and climatic information for the 29 provenances, three seed orchard and four seed stand collections included in the study. The number of included families per provenances is also given.

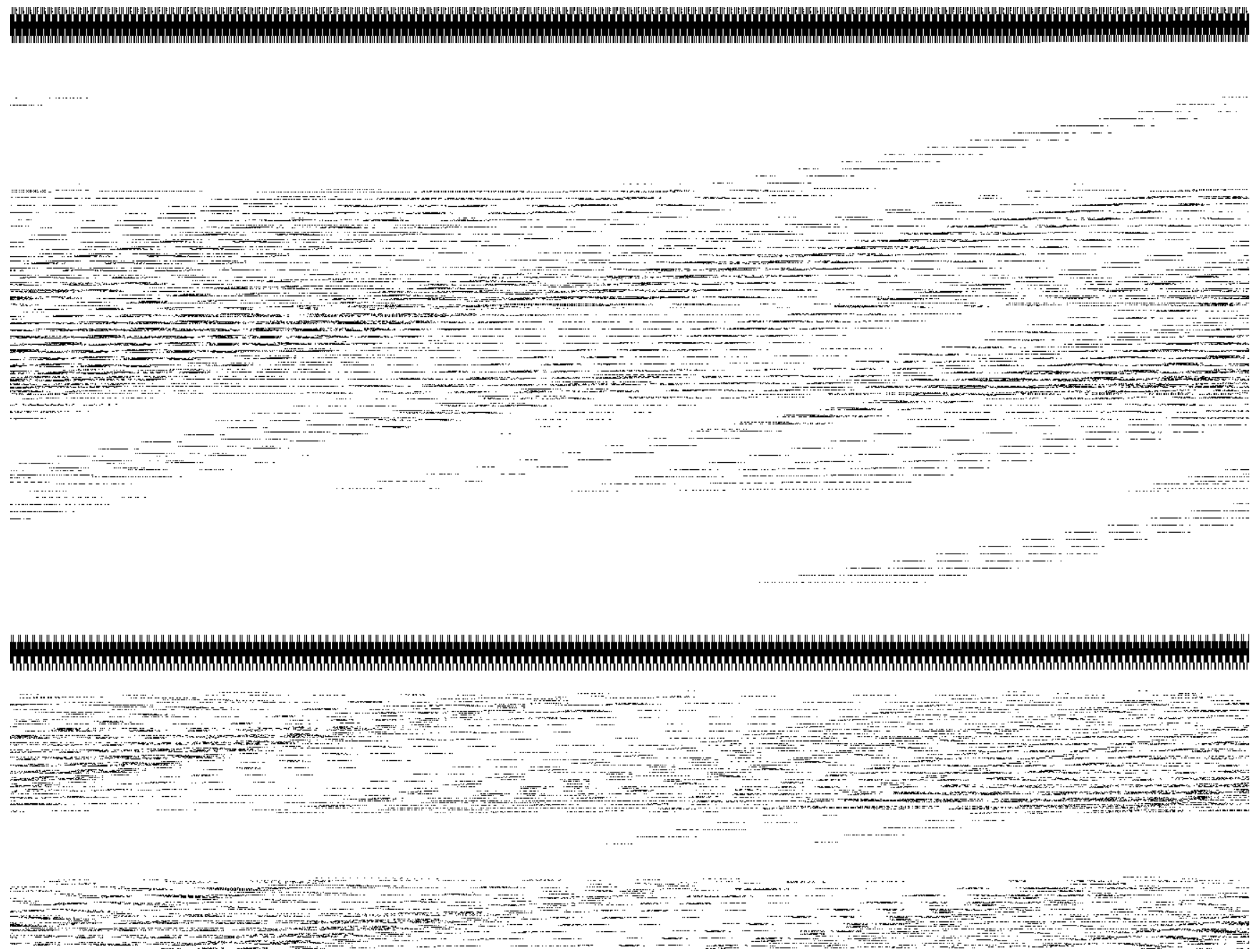

1) Elevations estimated based on map coordinates. L. suk. = Larix sukaczewii; $L$. sib. $=$ L. sibirica; $L$.caj. = L. cajanderi; L. gme. $=$ L. gmelinii; L. eur. $=$ L. $\mathrm{x}$ eurolepis $; \mathrm{Ru}=$ Russia, $\mathrm{Fi}=$ Finland; $\mathrm{S}=$ Sweden. ${ }^{2}$ MAT $=$ Mean annual temperature. ${ }^{3)} \mathrm{TCM}=\mathrm{Mean}$ temperature for coldest month. ${ }^{4)} \mathrm{A}-\mathrm{M}=$ Mean temperatures for April and May. ${ }^{5)} \mathrm{TWM}=\mathrm{Mean}$ temperature for warmest month and ${ }^{6)} \mathrm{CI}=$ continentality index.

the above mentioned provenance areas. In addition, three commercial Swedish and Finnish seed crops (Nos. 31-33) and four Russian bulk stand collections are included (Nos. 29, 30, 101 and 102) making totally ca. 17000 plants per site (Table 2 and Fig. 1). Seedlings were grown in 2002 at the Alstahaug nursery, in central Norway. In addition to the Swedish test series evaluated here, seed from the same material was distributed to 10 other countries resulting in a circumpolar participation of this progeny series of Eurasian larch species.

In the spring of 2003, 1-year-old container-seedlings were planted on three field tests in north, central, and south Sweden. All three sites were harrowed. The field tests were combined provenance and half-sib progeny trials. This study reports analyses of survival and height growth in the three sites after five growing seasons, that is, in October 2007.
The location and geographic description of the three field tests, Österbymo, Särna, and Järvträsk are presented in Table 1.

Each experimental locality was established with 20 plots with up to 300 seedlings per plot and with a spacing of $2 \times 2 \mathrm{~m}$. All plots were replicated in three blocks. Each plot was planted with one provenance, or when not enough plants were available of the provenance, with other provenances of similar regional origin. Families (and provenances if more than one) were completely randomized within plots. Each half-sib family was represented by 3 to 5 seedlings per block on each site, that is 9-15 trees/family and site. The number of families/ provenance is seen in Table 2.

The climatic data for the test sites and provenance locations were obtained from the Climate Research Unit (CRU) database available on the net (Ten minute clima- 
tology 2002 [http://www.cru.uea.ac.uk/cru/data/hrg/ tmc/]; NEw et al., 2002). Monthly mean temperatures for each locality were interpolated from these data based on temperature measurements during 1961-1990. If the nearest value point from the CRU data deviated less than 0.05 degrees the nearest value was used. Continentality index was based on Conrad's (1946) formula:

$$
C=\frac{1.7 A}{\sin \left(\varphi+10^{\circ}\right)}-14
$$

Where $C=$ continentality index, $A=$ the annual monthly temperature range, $\varphi=$ latitude.

\section{Inventory}

In September-October 2007, after five growing seasons in the field, survival was registered and height was measured for all living trees with $5 \mathrm{~cm}$ precision with a measure stick. Also recorded were browsing, frost damage, double leaders, insect damage, mechanical damage, and fungal attack. Survival was scored as $0=$ dead or $1=$ alive. In the analysis of height, all living trees except those with browsing injuries on the top shoot were included. Table 3 presents the number of measured plants of different species and sites.

Table 3. - Number of measured and analyzed trees, $\mathrm{n}$, for the different sites, species and traits (abbreviations according to Table 2).

\begin{tabular}{|c|c|c|c|}
\hline \multirow[b]{2}{*}{ Site } & \multirow[b]{2}{*}{ Species } & \multicolumn{2}{|l|}{$\mathrm{n}$} \\
\hline & & Survival & Height \\
\hline \multirow[t]{4}{*}{ Järvträsk } & L. suk & 5122 & 3916 \\
\hline & L. sib & 3008 & 1640 \\
\hline & L. caj & 1775 & 787 \\
\hline & L. gme & 2686 & 2037 \\
\hline \multirow[t]{4}{*}{ Särna } & L. suk & 5137 & 3346 \\
\hline & L. sib & 3035 & 1733 \\
\hline & L. caj & 1773 & 692 \\
\hline & L. gme & 2698 & 1553 \\
\hline \multirow[t]{4}{*}{ Österbymo } & L. suk & 5142 & 3330 \\
\hline & L sib & 3027 & 833 \\
\hline & L. caj & 1771 & 640 \\
\hline & L. gme & 2693 & 1980 \\
\hline
\end{tabular}

\section{Statistical analysis}

ArcSine-transformation of the survival data was made before analyses. To test correlations of geographical and climatic variables to survival and height, a Pearsons correlation test was performed by use of SPSS statistical software (SPSS for Windows version 12.0). Only provenance 1-28 and 34 were included in this analysis. The different species were analysed all together $(n=29)$ and species wise, L. sukaczewii $(\mathrm{n}=15)$, L. sibirica $(\mathrm{n}=6)$ and L. gmelinii and L. cajanderi as one group $(\mathrm{n}=8)$.

A genetic analysis was performed on the half-sib progeny material (Table 2). The analyses included estimation of additive genetic and phenotypic variances, heri- tabilities, genetic correlations and genetic coefficients of variation for height and survival using the ASReml 2.0 statistical software (GILMOUR et al., 2006). The heritabilities and genetic coefficients of variation estimated from them were considered significant if the quotient between the variance component from which they were estimated and its standard error was $\geq 2$, corresponding to a significant level of $\mathrm{p}<0.05$. When runs after repeated iterations did not converge, the parameter was set as non-estimable. The genetic model used was phenotypic effect $P=A+E$, where $P$ is the phenotypic effect, $A$ the additive effect and $E$ the environmental effect. The corresponding variances to be estimated were: $\sigma_{p}^{2}=\sigma_{A}^{2}+\sigma_{E}^{2}$. In the analyses the additive genetic effect $(A)$ was divided into provenance and family within provenance effects, respectively. In the statistical analysis the following mixed model was fitted for each test site:

$$
\begin{aligned}
Y_{i j k l m}= & \mu+b l_{i}+\operatorname{plant}(\text { plot })_{j}+\operatorname{row}(\text { plot })_{k} \\
& +\operatorname{prov}_{l}+\operatorname{fam}(\operatorname{prov}) m+e i j k l m,
\end{aligned}
$$

Where:

$Y_{i j k l m} \quad=$ individual observation of each trait of the $i j k l m^{\text {th }}$ plant position,

$b l_{i} \quad=$ fixed effect of the $i^{t h}$ block, $i=1-3$,

plant $(\text { plot })_{j}=$ random effect of the $j^{\text {th }}$ plant number within plot, $j=1-900(60 \times 15)$,

row $(\text { plot })_{k}=$ random effect of the $k^{\text {th }}$ row number within plot, $k=1-1200(60 \times 20)$,

prov $_{l} \quad=$ random effect of the $l^{\text {th }}$ provenance material, $l=1-15,1-6,1-4$ and $1-3$ for each of the larch species (L. suk, L. sib, L. caj and L. gme, abbreviations according to Table 2),

fam (prov) $m=$ random effect of the $m^{\text {th }}$ family within provenance,

for survival: $m=1-7$ to 68 (L. suk), 1-17 to 77 (L. sib), 1-24 to 58 (L. caj) and 1-58 to 60 (L. gme) (abbreviations according to Table 2),

for height growth: $m=1-7$ to 68 (L. suk), 1-16 to 77 (L. sib), 1-24 to 32,51 and 58 in each of the sites Järvträsk, Särna and Österbymo (L. caj) and 1-58 to 60 (L. gme),

eijklm = random residual (normal independent distribution assumed) with different $\sigma_{e}^{2}$ for each site, species and trait, ${ }_{i j k l m}=$ 1-n according to Table 3 .

Equations for the narrow-sense heritabilities, defined as the ratio of additive genetic variance to total phenotypic variance, were developed from FALCONER (1989) giving the following equations:

$$
\begin{aligned}
\text { Individual heritability: } & \hat{h}_{i}^{2}=4 \hat{\sigma}_{f a m(\text { prov })}^{2} / \hat{\sigma}_{f a m(\text { prov })}^{2} \\
& \left.+\hat{\sigma}_{\text {prov }}^{2}+\hat{\sigma}_{r e s}^{2}\right),
\end{aligned}
$$

Provenance + individual heritability:

$$
\left.\hat{h}_{p+i}^{2}=\left(\hat{\sigma}_{p r o v}^{2}+4 \hat{\sigma}_{\text {fam(prov })}^{2}\right) / \hat{\sigma}_{\text {fam }(\text { prov })}^{2}+\hat{\sigma}_{\text {prov }}^{2}+\hat{\sigma}_{r e s}^{2}\right) \text {, }
$$

Multiplication by 4 is made since the estimates are based on half-sib families. 
The additive genetic correlation between trait $i$ and $j$ as

$$
\hat{r}_{A_{i j}}=\hat{r}_{A_{i} A_{j}}=\frac{\hat{\sigma}_{u_{i} u_{j}}}{\hat{\sigma}_{u_{i}} \hat{\sigma}_{u_{j}}},
$$

define terms in (FALCONER, 1989).

And the additive genetic coefficients of variation, $C V_{A}$, for survival and height as:

$$
\begin{gathered}
\hat{C} V_{A i}=\hat{\sigma}_{A i} / \text { phenotypic mean, where } \hat{\sigma}_{A i}=\left(4 \hat{\sigma}_{\text {fam }(\text { prov })}\right)^{1 / 2} \\
\hat{C} V_{A(p+i)}=\hat{\sigma}_{A(p+i)} / \text { phenotypic mean, where } \\
\hat{\sigma}_{A(p+i)}=\left(\hat{\sigma}^{2}{ }_{\text {prov }}+4 \hat{\sigma}_{\text {fam }(\text { prov })}^{2}\right)^{1 / 2}
\end{gathered}
$$

Owing to large family $\times$ site interaction and considerable climatic differences among test sites (Table 1), data analysis was conducted separately for each site and the four different Larix species were analysed separately. Plant effect was necessary to include in the model since the Järvträsk site was located in a sharp slope across plant numbers, and row number to compensate for a specific environmental effect caused by row-wise planting. This decreases the degree of freedom for family effect which reduces the precision in the genetic parameters.

\section{Results}

\section{Survival and height growth at the three test sites}

The survival was highest in Järvträsk with 59-78\% among the four species, while it was lower in Särna and Österbymo (51-66\% and 34-74\%, respectively) (Table 4). Average heights were lowest in the most northern site, Järvträsk, with $0.84-1.1 \mathrm{~m}$ among the four species followed by Särna $(0.93-1.2 \mathrm{~m})$ and Österbymo $(1.3-2.6 \mathrm{~m})$.

\section{Survival and height growth for species and provenances}

Among species, Larix sukaczewii showed the highest survival at the two northern sites (Table 4). The phenotypic coefficients of variation were on the whole large (above $50 \%$ ). At Järvträsk the most northern provenances (Nos. 5 to 7 , Lat. $66^{\circ} 00^{\prime}-66^{\circ} 56^{\prime} \mathrm{N}$ ) showed poor height growth and lower survival than provenances from Arkhangelsk (Lat. $62^{\circ}-64^{\circ} \mathrm{N}$ ) (Table 4). At the southern test site, Österbymo, the provenance differences were largest. The most northern origins of L. sukaczewii had very high mortality, while many southern provenances originating from $55-57^{\circ} \mathrm{N}$ performed well. Two of the Far Eastern provenances of L. gmelinii had good survival at Österbymo while the more northern provenance from Kamchatka had lower survival. All L. sibirica provenances showed low survival at Österbymo, as did the northern provenance of L. cajanderi (No. 22) which had no surviving seedlings at all after five years. Among the $L$. sibirica provenances, the most western (No. 8) provenance had highest survival on the two northern sites; the height growth of this provenance was, however, not among the best within this species. Larix gmelinii from Evenkiya (Central Siberia, No. 34) was planted only in Särna and suffered from high mortality there.
Best height growth in all three sites was shown by Larix gmelinii while L. sibirica generally had poorest growth (Table 4). The phenotypic coefficients of variation were low, 4-6\%. L. sukaczewii showed the largest variation among provenances, especially in Särna and Österbymo (Table 4). Provenances from the south Ural and lower latitudes in the North West area, Vetluga (No. 4) and Ivanovo (No. 29), grew best. The northernmost provenances (Nos. 5, 6 and 7) demonstrated generally poor height growth.

Among the L. sibirica provenances, provenance No. 20, Aktash from high altitude in the Altai Mountains, had the slowest growth. There were no big differences among the other provenances within this species. The relative competitiveness of the species was best on the most northern site.

In relation to the other species $L$. cajanderi from Magadan (Nos. 23-25) grew best on the most northern site, Järvträsk. The most northern provenance, Zhigansk (No. 22) from interior Siberia grew poorly on the two northern sites. In the southern test site, Österbymo, it did not survive at all (Table 4).

L. gmelinii demonstrated the best height growth among all species on all three test sites. The provenance from Sakhalin (No. 27) produced best on the two northern sites and No. 26 from Khabarovsk had the best height growth on the southern site. The more northern provenance of L. gmelinii from Kamchatka (No. 28) had lower mean height than the Sakhalin and Khabarovsk provenances at all sites.

\section{Geographical and climatic variables influence on survival and height growth}

In Järvträsk and Särna, survival for Larix sukaczewii was weakly correlated to geographic and climatic variables, while height growth was under stronger influence (Table 5). Provenances from more continental areas (high continentality index) generally had lower survival than provenances originating from more maritime regions, especially in Järvträsk with $r=-0.70(\mathrm{p}<0.01)$. In the southern test site, Österbymo, northern provenances showed low survival and poor height growth $r=-0.78(\mathrm{p}<0.01)$, but overall a more favourable temperature climate favoured survival and especially growth.

For L. sibirica, latitude was only a significant factor for survival at Särna where northern provenances had better survival. Height growth was strongest influenced by temperature during April and May, with provenances originating in climates with milder temperatures having better height growth (Data not shown).

For L. gmelinii and L. cajanderi, latitudinal origin of provenances was negatively correlated to height growth at site Särna $(\mathrm{p}<0.01)$ and Österbymo $r=-0.91(\mathrm{p}<0.01)$ and $r=-0.89(\mathrm{p}<0.05)$. Northern provenances had thus lower mean heights (Table 6). Also longitudinal origin of provenances had great effect with Far eastern populations having higher survival than provenances originating in interior Siberia. Continentality index (CI) was negatively correlated with survival $(\mathrm{p}<0.01)$ at the two northern sites Järvträsk and Särna. In Österbymo, a 
strong correlation between temperature climate of provenance origin and survival was observed, $r=-0.91$ $(\mathrm{p}<0.01)$ for TCM and $r=0.92(\mathrm{p}<0.01)$ for MAT. Provenances originating in warmer climates had higher survival.

The effect of the latitudinal origin of the different provenances within L. sukaczewii for the survival on the different sites is seen in Fig. 2. On the southern site, provenances originating from roughly the same latitudes as the test site (Lat. $57^{\circ} \mathrm{N}$ ) have highest survival. Provenances originating approx. north of latitude $65^{\circ} \mathrm{N}$ show low survival on this site.

On the two northern sites (Särna, Lat. $61^{\circ} \mathrm{N}$, Järvträsk, Lat. $65^{\circ} \mathrm{N}$ ) the pattern is not as clear, howev-

Table 4. - Survival and height growth of the included provenances after five growing seasons on three test sites in Sweden. The numbers marked with bold text are the 10 provenances with the highest survival, height growth, respectively on each site.

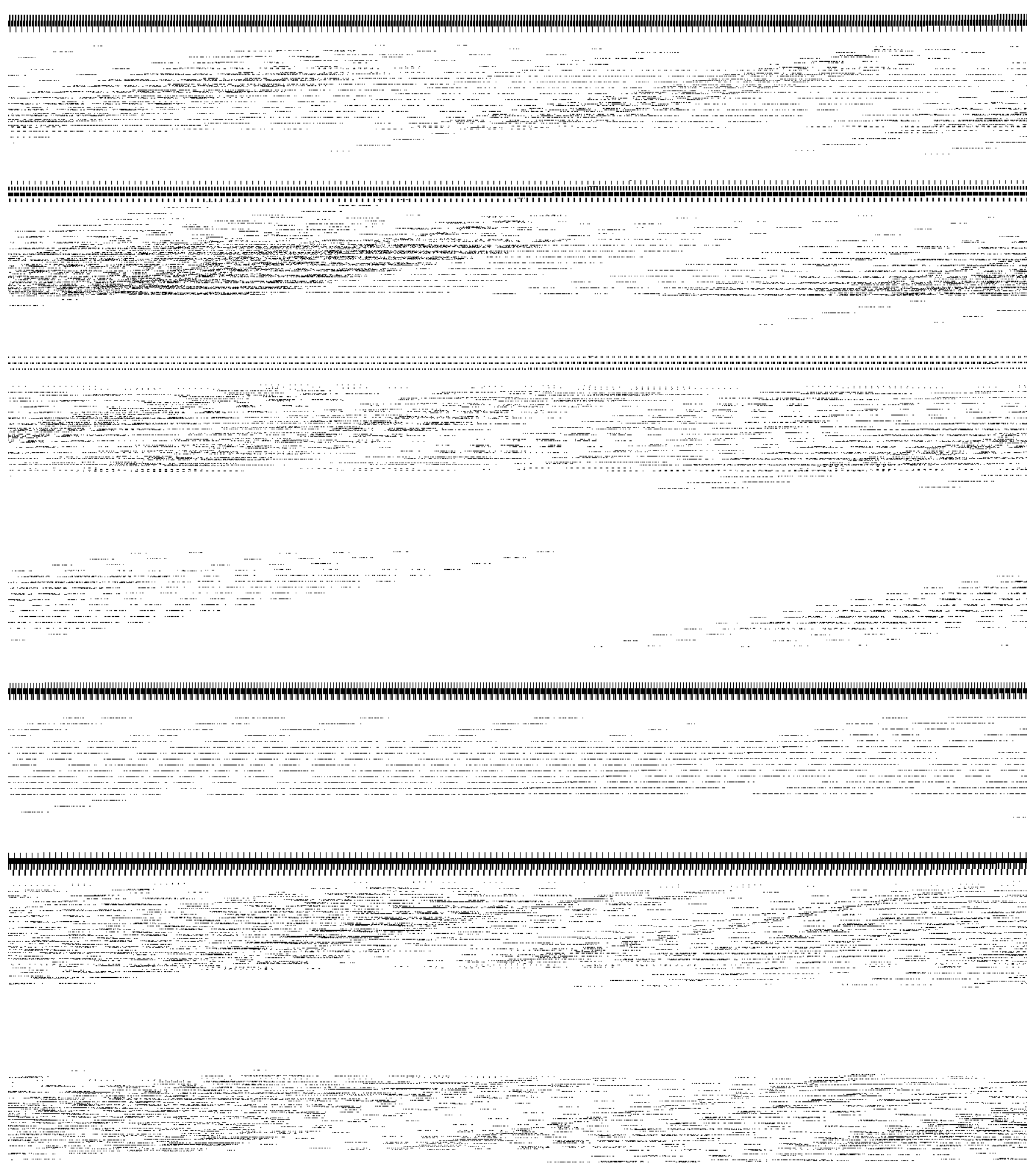

- = Not planted on this site. For abbreviations see table 2 . 
Table 5. - Phenotypic correlation coefficients between geographical and climatic variables with survival and height growth of Larix sukaczewii $(\mathrm{n}=15)$.

\begin{tabular}{|c|c|c|c|c|c|c|}
\hline \multirow[t]{2}{*}{ Variable } & \multicolumn{3}{|l|}{ Survival } & \multicolumn{3}{|l|}{ Height } \\
\hline & Österbymo & Särna & Järvträsk & Österbymo & Särna & Järvträsk \\
\hline Lat. ${ }^{\circ} \mathrm{N}$ & $-0.78 * *$ & 0.28 & 0.45 & $-0.86 * *$ & $-0.82 * *$ & -0.27 \\
\hline Long. ${ }^{\circ} \mathrm{E}$ & -0.45 & $-0.53 *$ & $-0.55 *$ & 0.06 & -0.30 & $-0.74 * *$ \\
\hline $\mathrm{TCM},{ }^{\circ} \mathrm{C}$ & $0.91 * *$ & 0.23 & 0.09 & $0.54 *$ & $0.82 * *$ & $0.81 * *$ \\
\hline $\mathrm{MAT},{ }^{\circ} \mathrm{C}$ & $0.96 * *$ & 0.08 & -0.10 & $0.76 * *$ & $0.91 * *$ & $0.71 * *$ \\
\hline CI & -0.34 & -0.51 & $-0.52 *$ & 0.18 & -0.19 & $-0.70 * *$ \\
\hline $\mathrm{A}-\mathrm{M},{ }^{\circ} \mathrm{C}$ & $0.96 * *$ & -0.06 & -0.24 & $0.87 * *$ & $0.94 * *$ & $0.59 *$ \\
\hline
\end{tabular}

Note: ${ }^{*}=$ significant at $\mathrm{p}<0.05,{ }^{* *}=$ significant at $\mathrm{p}<0.01$. For abbreviations see table 2.

Table 6. - Phenotypic correlation coefficients between geographical and climatic variables with survival and height growth of Larix gmelinii and L. cajanderi $(\mathrm{n}=6)$.

\begin{tabular}{lllllll}
\hline Variable & \multicolumn{3}{c}{ Survival } & & \multicolumn{3}{c}{ Height } \\
& Österbymo & Särna & Järvträsk & Österbymo & Särna & Järvträsk \\
\hline Lat. ${ }^{\circ} \mathrm{N}$ & $-0.77 *$ & -0.47 & -0.60 & $-0.89 *$ & $-0.91 * *$ & -0.63 \\
Long. ${ }^{\circ} \mathrm{E}$ & 0.59 & $0.86 * *$ & $0.84 *$ & $-0.92 *$ & 0.57 & 0.49 \\
$\mathrm{CI}$ & -0.75 & $-0.94 * *$ & $-0.92 * *$ & $0.89 *$ & -0.70 & -0.64 \\
$\mathrm{TCM}$ & $0.91 * *$ & $0.89 *$ & $0.96 * *$ & 0.13 & $0.87 * *$ & $0.84 *$ \\
$\mathrm{MAT}$ & $0.92 * *$ & 0.68 & $0.79 *$ & $0.82 *$ & $0.98 * *$ & $0.92 * *$ \\
$\mathrm{~A}-\mathrm{M}$ & 0.68 & 0.17 & 0.40 & $0.86 *$ & $0.78 *$ & $0.77 *$
\end{tabular}

Note: ${ }^{*}=$ significant at $\mathrm{p}<0.05^{* *}=$ significant at $\mathrm{p}<0.01$. For abbreviations see table 2 .

er. Both at Särna and Järvträsk, survival seemed to be at maximum for provenances originating between Lat. $62-65^{\circ} \mathrm{N}$. The survival decreases for the most northern provenances.

The relationship between latitudinal origin of provenance and survival was curvilinear. The best fit was obtained by using a quadratic equation.

\section{Genetic parameters}

The analyses of the present data did not reveal any clear and systematic genetic pattern for survival and height at the family level. Instead, only a few significant individual heritabilities $\left(h^{2}{ }_{i}\right)$ were obtained, and they were most often very low (below 0.10 ) (Tables $7 a, b)$. The combined family+provenance heritabilities $\left(h^{2}{ }_{p+i}\right)$ were on the whole higher than the individual heritabilities. Still, they were with one exception non-significant. There were no significant genetic correlations between height and survival (data not shown).

For survival, the individual additive genetic coefficients of variation $(C V A(i))$ were, when signif-

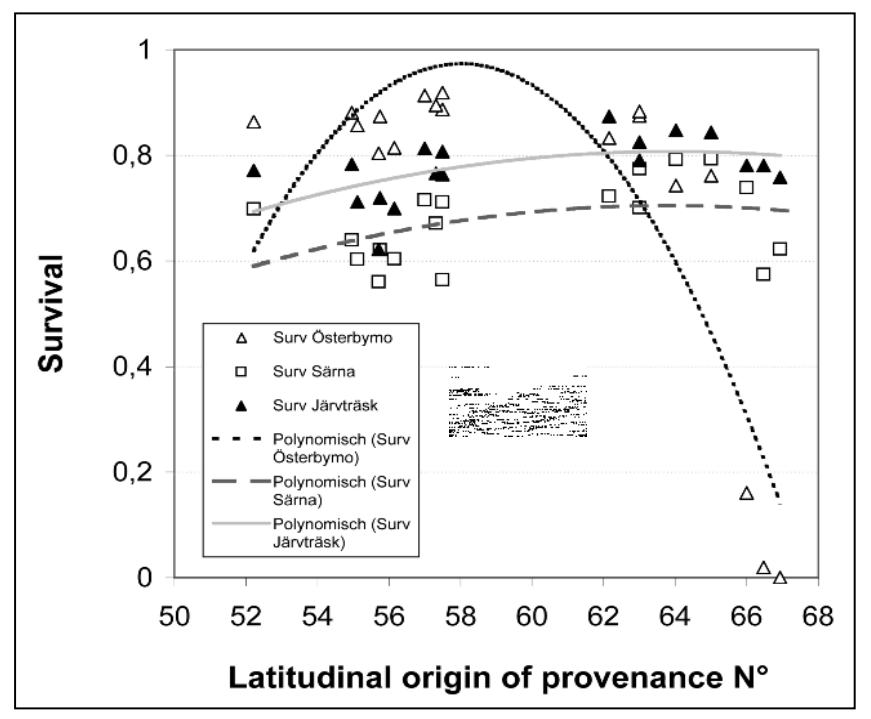

Figure 2. - Latitudinal origin of the different provenances within L. sukaczewii and corresponding average survival on the three sites. The latitudes of the sites are indicated on the $\mathrm{x}$-axis. Ös = Österbymo; Sä = Särna and Jä = Järvträsk. 
Table 7. - Heritabilities \pm standard errors and genetic (additive) coefficients of variation $(\%)^{1}$. Figures in bold are significant on the 0.05 level, i.e. at least one of the underlying variance components is non-significant: a) Survival, b) Height.

a)

\begin{tabular}{|c|c|c|c|c|c|c|c|c|c|c|c|c|}
\hline \multirow[b]{2}{*}{ Species } & \multirow[b]{2}{*}{$h_{i}^{2}$} & \multicolumn{3}{|c|}{ Järvträsk } & \multicolumn{4}{|c|}{ Särna } & \multicolumn{4}{|c|}{ Österbymo } \\
\hline & & $\begin{array}{c}\mathrm{CV}_{\mathrm{A}}(\mathrm{i}) \\
(\%)\end{array}$ & $h_{p+i}^{2}$ & $\begin{array}{c}\text { CVA(p+i) } \\
(\%)\end{array}$ & $h_{i}^{2}$ & $\mathrm{CV}_{\mathrm{A}}(\mathrm{i})(\%)$ & $\boldsymbol{h}_{p+i}^{2}$ & CVA(p+i) $(\%)$ & $h_{i}^{2}$ & $\mathrm{CV}_{\mathrm{A}}(\mathbf{i})(\%)$ & $h_{p+i}^{2}$ & $\operatorname{CVA}(\mathbf{p}+\mathbf{i})(\%)$ \\
\hline L. suk & $\begin{array}{c}0.032 \pm \\
0.026\end{array}$ & 9.31 & $0.042 \pm 0.026$ & 10.6 & $\begin{array}{c}0.032 \pm \\
0.026\end{array}$ & 12.3 & $0.050 \pm 0.027$ & 15.3 & $0.023 \pm 0.014$ & 10.8 & $0.54 \pm 0.091$ & 52.6 \\
\hline L. sib & $\begin{array}{c}0.093 \pm \\
0.037\end{array}$ & 26.6 & $0.19 \pm 0.062$ & 37.7 & $\begin{array}{c}0.031 \pm \\
0.030\end{array}$ & 14.7 & $0.058 \pm 0.035$ & 20.1 & $0.16 \pm 0.043$ & 63.7 & $0.37 \pm 0.093$ & 97.0 \\
\hline L. $c a j$ & $\begin{array}{c}0.042 \pm \\
0.030\end{array}$ & 22.3 & $0.70 \pm 0.16$ & 91.2 & $\begin{array}{c}0.046 \pm \\
0.036\end{array}$ & 26.4 & $0.29 \pm 0.15$ & 65.9 & $0.0057 \pm 0.018$ & 9.74 & $0.63 \pm 0.19$ & 102.6 \\
\hline L. gme & $\mathrm{ne}^{2)}$ & $n e^{2)}$ & $0.055 \pm 0.037$ & ne & $\begin{array}{c}0.095 \pm \\
0.038\end{array}$ & 25.3 & $0.26 \pm 0.13$ & 41.7 & $0.074 \pm 0.035$ & 16.2 & $0.25 \pm 0.14$ & 29.9 \\
\hline
\end{tabular}

b)

\begin{tabular}{|c|c|c|c|c|c|c|c|c|c|c|c|c|}
\hline \multirow[b]{2}{*}{ Species } & \multicolumn{4}{|c|}{ Järvträsk } & \multicolumn{4}{|c|}{ Särna } & \multicolumn{4}{|c|}{ Österbymo } \\
\hline & $h_{i}^{2}$ & $\begin{array}{c}\mathrm{CV}_{\mathrm{A}}(\mathrm{i}) \\
(\%)\end{array}$ & $h_{p+i}^{2}$ & $\begin{array}{c}\text { CVA(p+i) } \\
(\%)\end{array}$ & $h_{i}^{2}$ & $\mathrm{CV}_{\mathrm{A}}(\mathrm{i})(\%)$ & $h_{p+i}^{2}$ & CVA(p+i) $(\%)$ & $h_{i}^{2}$ & $\mathrm{CV}_{\mathrm{A}}(\mathrm{i})(\%)$ & $h_{p+i}^{2}$ & CVA(p+i) $(\%)$ \\
\hline L. suk & $\begin{array}{c}0.021 \pm \\
0.031\end{array}$ & 7.28 & $0.087 \pm 0.040$ & 14.7 & $\begin{array}{c}0.049 \pm \\
0.031\end{array}$ & 14.9 & $0.29 \pm 0.073$ & 36.1 & $0.10 \pm 0.032$ & 15.4 & $0.54 \pm 0.086$ & 35.5 \\
\hline L. sib & $\begin{array}{c}0.058 \pm \\
0.046\end{array}$ & 14.0 & $0.22 \pm 0.093$ & 23.1 & $\begin{array}{l}0.13 \pm \\
0.057\end{array}$ & 19.4 & $0.31 \pm 0.098$ & 29.8 & $0.14 \pm 0.075$ & 17.7 & $0.38 \pm 0.12$ & 29.9 \\
\hline L. $c a j$ & $\begin{array}{c}0.0089 \pm \\
0.044\end{array}$ & 5.78 & $0.42 \pm 0.20$ & 39.4 & $\begin{array}{c}0.079 \pm \\
0.069\end{array}$ & 19.4 & $0.50 \pm 0.19$ & 48.8 & $\mathrm{ne}^{2)}$ & ne & $0.12 \pm 0.11$ & 14.4 \\
\hline L. gme & $\begin{array}{c}0.038 \pm \\
0.036\end{array}$ & 11.2 & $0.28 \pm 0.18$ & 30.6 & $\begin{array}{c}0.0083 \pm \\
0.041\end{array}$ & 4.12 & $0.23 \pm 0.18$ & 21.5 & $0.021 \pm 0.020$ & 6.40 & $0.76 \pm 0.18$ & 38.8 \\
\hline
\end{tabular}

1) $h^{2}$, individual heritability; $h_{p+i}^{2}$, provenance + family heritability; $\mathrm{CV}_{\mathrm{A}}(\mathrm{i})$, individual additive genetic coefficient of variation; $\mathrm{CVA}(\mathrm{p}+\mathrm{i})$, Provenance + Family additive genetic coefficient of variation.

2) ne, not possible to estimate.

Table 8. - Mean values $(\mathrm{Mv})$, phenotypic variances on individual tree level $\left(\mathrm{V}_{\mathrm{p}}\right) \pm$ standard errors and phenotypic coefficients of variation $\left(\mathrm{CV}_{\mathrm{p}}\right)\left(\mathrm{CV}_{\mathrm{p}}=\sqrt{\mathrm{Vp}} / \mathrm{Mv}(\%)\right)$ : a) Survival, b) Height.

a)

\begin{tabular}{|c|c|c|c|c|c|c|c|c|c|}
\hline \multicolumn{4}{|c|}{ Järvträsk } & \multicolumn{2}{|c|}{ Särna } & \multicolumn{4}{|c|}{ Österbymo } \\
\hline Species ${ }^{1)}$ & $\operatorname{Mv}(\%)$ & $\mathbf{v}_{p}$ & $\mathrm{CV}_{\mathrm{p}}(\%)$ & $\operatorname{Mv}(\%)$ & $\mathbf{v}_{\mathbf{p}}$ & $\mathrm{CV}_{\mathrm{p}}(\%)$ & $\operatorname{Mv}(\%)$ & $\mathbf{v}_{\mathbf{p}}$ & $\mathrm{CV}_{\mathrm{p}}(\%)$ \\
\hline L. suk & 78 & $0.16 \pm 0.0036$ & $52.2 \%$ & 66 & $0.20 \pm 0.0046$ & $68.8 \%$ & 73 & $0.21 \pm 0.042$ & $62.8 \%$ \\
\hline$L_{\Delta} s i b$ & 59 & $0.23 \pm 0.016$ & $81.3 \%$ & 58 & $0.23 \pm 0.0077$ & $83.9 \%$ & 34 & $0.19 \pm 0.027$ & $128.2 \%$ \\
\hline L. $c a j$ & 64 & $0.24 \pm 0.13$ & $76.5 \%$ & 51 & $0.23 \pm 0.0046$ & $95.3 \%$ & 55 & $0.22 \pm 0.11$ & $85.3 \%$ \\
\hline L. gme & 76 & $0.15 \pm 0.0045$ & $51.8 \%$ & 58 & $0.22 \pm 0.037$ & $80.9 \%$ & 74 & $0.19 \pm 0.035$ & $58.9 \%$ \\
\hline
\end{tabular}

b)

\begin{tabular}{|c|c|c|c|c|c|c|c|c|c|}
\hline \multirow[b]{2}{*}{ Species ${ }^{1}$} & \multicolumn{3}{|c|}{ Järvträsk } & \multicolumn{3}{|c|}{ Särna } & \multicolumn{3}{|c|}{ Österbyme } \\
\hline & $\operatorname{Mv}(\mathrm{cm})$ & $\mathbf{v}_{\mathrm{p}}$ & $\mathrm{CV}_{\mathrm{p}}(\%)$ & $\mathbf{M v}(\mathbf{c m})$ & $v_{p}$ & $\mathrm{CV}_{\mathrm{p}}(\%)$ & $\mathbf{M v}(\mathrm{cm})$ & $\mathbf{v}_{\mathbf{p}}$ & $\mathrm{CV}_{\mathrm{p}}(\%)$ \\
\hline L. suk & 83 & $13.06 \pm 0.47$ & $4.4 \%$ & 105 & $41.38 \pm 3.96$ & $6.1 \%$ & 180 & $75.28 \pm 13.45$ & $4.8 \%$ \\
\hline L. sib & 86 & $18.99 \pm 2.59$ & $5.1 \%$ & 94 & $21.02 \pm 2.56$ & $4.9 \%$ & 140 & $44.52 \pm 7.56$ & $4.8 \%$ \\
\hline L. $c a j$ & 113 & $42.75 \pm 14.52$ & $5.8 \%$ & 104 & $35.36 \pm 1.24$ & $5.7 \%$ & 165 & $45.63 \pm 6.27$ & $4.1 \%$ \\
\hline L. gme & 115 & $36.77 \pm 9.19$ & $5.3 \%$ & 130 & $35.28 \pm 7.89$ & $4.6 \%$ & 225 & $153.6 \pm 113.7$ & $5.5 \%$ \\
\hline
\end{tabular}

1) Abbreviations according to Table 2.

icant, ca. $20 \%$ with one exception (Table 7a). No significant $C V_{A(p+i)}$ were estimated. For height, they were generally non-significant but a tendency was that both $C V_{A(i)}$ and $C V_{A(p+i)}$ were $10-40 \%$
(Table 7b). Overall, the results at this early age indicate possible genetic gains in survival whereas possible genetic gains in height growth are more uncertain. 


\section{Discussion}

\section{Survival and height growth at the three test sites}

Most important, when establishing new forests in harsh areas is to achieve a satisfactory survival. The two northern sites (Järvträsk and Särna) are located in severe climates. Temperature sum is 650 and 725 d.d. for the two sites. Another measure of the severity of a planting site, developed for northern Sweden, is severity index. It was defined by ERIKSSON et al. (1980) as the mortality of the local Scots pine provenance at a site after 20 years. The severity index is about $65 \%$ for Järvträsk and about $55 \%$ for Särna. Contrary to the severity index, the survival after five growing seasons was higher in the most northern site Järvträsk than in Särna. One explanation to the lower survival at Särna might be the very stony soil conditions there, resulting in occasional poor soil scarification and planting outside of the scarified tracks, leading to high initial mortality. The survival at Särna was 69.4.\% after two growing seasons compared to $84.9 \%$ for Järvträsk (MARTINSSON and TAKATA, 2005). After this, the survival in Särna has been on the same level as in Järvträsk. The location of the site at Järvträsk, in a rather steep slope could have lowered the risk of frost damage in the young seedlings, which also could explain the higher initial survival there compared to Särna. The rather low mean survival $(59 \%)$ at the southern site, Österbymo (Table 4) is explained by heavy mortality in the most northern and high altitude provenances.

\section{Survival and height growth for species}

For L. sukaczewii longitudinal origin had greater effect than latitude on survival at both Järvträsk and Särna, with eastern provenances showing lower survival. In north-western Russia, continentality increases with increasing longitudinal (eastern) origin. The site at Järvträsk has a continentality index (CI, where a higher value indicate a more continental climate) of 34 and the Arkhangelsk provenances 38-40, while the very northern and southern Ural provenances have a CI of 48-56 (Table 2). EysteInsson et al. (2009) studied the same provenances as included in this paper and found a negative correlation between longitudinal provenance origin (i.e. also CI) and frost resistance, with north western provenances least damaged by frost. The reason for the better frost resistance in north western provenances was suggested to be the maritime influence these provenances are exposed to. The higher survival for the Arkhangelsk provenances in the present study may thus be connected with their higher frost resistance, shown in Eysteinsson et al. (2009). The good survival of the L. cajanderi provenances 23-25 from Magadan situated close to the Sea of Okhotsk and maritime influenced provenances of $L$. gmelinii (Nos. 27-28) also strengthen the idea that more maritime provenances are preferable in the semi-maritime climate of Sweden. This is supported by TIGERSTEDT (1993).

Comparing $L$. sukaczewii and $L$. sibirica, the results from this early evaluation are in accordance with previous provenance research in Iceland where $L$. sukaczewii had clearly better adaptation than the more continental provenances of L. sibirica (EYSTEINSSON and SkÚLASSON,
1995). Similar conclusions are also drawn from a Finnish field experiment in Rovaniemi in northern Finland (Lat. $66^{\circ} 29^{\prime} \mathrm{N}$ ), L. sukaczewii from Arkhangelsk proved to be superior in survival compared to provenances of $L$. sibirica (HAGMAN, 1995).

At site Österbymo, southern provenances of $L$. sukaczewii showed good survival and height growth while the most northern origins had low survival (Fig. 2). L. sibirica is not well adapted to this site with only $2-56 \%$ survival (Table 4). Siberian larch ( $L$. sukaczewii and L. sibirica) has generally been considered as a species only for northern Sweden (SchotTE, 1917; EDLUND, 1966). The early results from Österbymo confirm the bad adaptation of $L$. sibirica to southern Swedish conditions, but give an indication that southern provenance of $L$. sukaczewii and also $L$. gmelinii origins from the Russian Far East (Nos. 26 from Khabarovsk and 27 from Sakhalin) might be well adapted to harsher sites also in southern Sweden. It is still though too early in the evaluation stage to draw certain conclusions about this. L. gmelinii provenances, Nos. 26 and 27 demonstrated with one exception the best height growth in all test sites, also including the hybrid larch (No. 33), which has been proven to have a very fast juvenile growth in trials in southern Sweden (LARSSON-STERN, 2003; STENER, 2007).

\section{Survival and height growth of provenances and stand seed sources}

For survival, there was a modest but not significant correlation with latitude at Järvträsk (Lat. N 65¹1') (Table 5). Provenances from southern Ural (Nos. 9-16) and No. 4 from Nishnij Novgorod (Lat $52-57^{\circ} \mathrm{N}$ ) had generally lower survival than the Arkhangelsk provenances originating from latitudes $62-65^{\circ} \mathrm{N}$ (Nos. $1-3$ and 101-102), which seem as the best choice at the Järvträsk site. To use provenances from further north in Russia than Arkhangelsk does not increase the survival at Järvträsk, the provenances originating from Lat. $66^{\circ} \mathrm{N}$ actually have lower survival than the more southern Arkhangelsk provenances. This indicates that Russian larch differs from Scots pine in the aspect of reaction to provenance transfer. Besides considering longitudinal origin and CI, larch could be transferred north, at least 2-3 latitudes, with good results. Scots pine on the other hand should be transferred south to achieve highest survival on harsh localities in northern Sweden (EICHE, 1966; ERIKSSON et al., 1980). In fig. 2, the three most northern provenances which have lower survival also originate from a more continental climate, indicating that the effect of latitude could be confounded with the effect of continentality.

REHFELDT et al. (1999) showed that among $L$. sukaczewii, L. sibirica and L. gmelinii, the most important factors determining survival and growth when introduced to Alberta, Canada, were mean annual temperature, temperature range between warmest and coldest months, mean temperature for the coldest month and temperature/precipitation ratio. They concluded that the best survival and growth would be achieved by choosing provenances from a climate that most resembles that of the new planting site. 
SIMAK (1979) discussed planting of L. sukaczewii in northern Sweden and emphasised the climatic differences between north-western Russia and northern Sweden. To reach a similar temperature regime in Sweden as in Russia, L. sukaczewii should according to Simak be transferred 3-5 latitudes north. As the termination of growth mainly is controlled by light conditions and growth cessation starts when a certain critical night length is reached (DORMLING et al., 1968; SIMAK, 1970, 1979), such a northern transfer would extend the growth period in the autumn and possibly increase the risk of autumn frost damage. These apprehensions have so far not been fulfilled at the Järvträsk site. Even provenances transferred 7-8 latitudes north (No. 29 Ivanovo and 10 Visim) have shown good survival and frost resistance (EYSTEINSSON et al., 2009) after five growing seasons. It has, however, been shown by EICHE (1966) and ERIKSSON et al. (1980) that mortality in harsh climates is a serious risk for trees up to at least 20 years of age. This and the location of the Järvträsk site, at a quite steep not frost-prone slope, makes it therefore too early to recommend long northern transfer at these latitudes in Sweden.

The latitudinal origin of provenance was also a strong predictor of height growth for all species in our test series. Southern provenances had generally a better height growth than northern ones, and this is most pronounced on sites Österbymo and Särna (Table 5 and 6). The same importance of latitudinal origin and the length of the growing period for height growth in Russian larches was obtained in LUKKARINEN et al. (2009) where the same provenances as in the present study was analysed.

Among nine larch species, including L. sukaczewii, L. sibirica and $L$. gmelinii, tested in a temperate climate in New Brunswick, Canada (Lat. $45^{\circ} 52^{\prime} \mathrm{N}$ ) (CARSwELL and Morgenstern, 1995), there was also a significant correlations between growth cessation and latitude and growth cessation and height. At the most northern site in our study, however, the correlation between latitude and height growth was lower and non-significant (Table 5 and 6 ). The reason for this might be that at these latitudes some southern provenances grow too long in the autumn and get injured by frost, reducing height growth.

Climatic variables showed strong correlation with survival and height growth of the 15 Larix sukaczewii provenances. Survival of provenances was more strongly correlated to climatic variables at the southern site Österbymo where the mean annual temperature and mean temperature for April and May explained $92 \%$ of the variation in survival between the different provenances (Table 5). The temperature in spring is of importance as it regulates the start of growth for trees. Provenances originating from a cold spring climate are regulated to start their growth when a certain heat sum is reached (CARSWELL and MORGENSTERN, 1995; ERIKSSON et al., 2006). When transferred to a site with warmer spring climate, these provenances will initiate their growth early which makes them susceptible to spring frost damage. This could be the main reason for the high mortality in the most northern and continental prove- nances (Nos. 5-8, 20 and 22) at Österbymo. Frost damage has also consequences for height growth. A positive correlation between spring frost resistance and juvenile height growth in L. sukaczewii was found by EYsTEINSSON (2002).

Most climate models for Sweden implicate that the temperature increase during this century will be greatest in the winter, that is, a more maritime climate is expected (KJELLSTRÖM and LIND, 2009). Studies of the ice cover of the Gulf of Bothnia show that the maximum ice extent has decreased considerably during the last 20 year period (POLAR RESEARCH GROUP, http://arctic. atmos.uiuc.edu/cryosphere, June 2009). Milder winters with temperatures fluctuating around zero degrees can disturb the winter dormancy of trees. This has been observed in Iceland where larch has been damaged by spring frost owing to warm spells during late winter (EYSTEINSSON and SkÚLASSON, 1995). Similarly, in Österbymo the Magadan provenances (Nos. 23-25) initiated growth as early as in February during the winter of 2007. The trees generally survived the frost injuries but severe damages on top shoots were recorded later that year (MARTINSSON and LESINSKI, 2007). As a consequence of a suggested warmer climate, the importance of choosing materials adapted to maritime climate is thus emphasized for areas with increasing risks for warm spells.

Best survival, combining results from the three sites, had the Finnish seed orchard seed source Lassinmaa (Table 4). This seed orchard is based on selected plustrees from northern Finland (see www.evira.fi for details on this seed source), and it gives an indication of the potential for larch breeding. This seed source originates from the Raivola larch forest in Russian Karelia and it has also shown remarkably wide ecological adaptation in Finland. MIKOLA and VAKKARI (1995) studied genotype $\mathrm{x}$ environment interactions in families of second generation seed sources of the Raivola provenance and found that its broad adaptation and stable performance in many different environments mainly was owing to its high individual plasticity. This material has at least two generations of natural and man-made selection in semimaritime climate, first in Raivola and then in Finnish stands where the plus trees have been selected (RUOTSALAINEN pers. comm., 2009). The Lassinmaa seed orchard is located in a more maritime area, continentality index, CI, of 31 , compared to the climate of the origin of the Russian provenances of L. sukaczewii (CI 38-56). The climate in central Finland where the Lassinmaa seed orchard is located resembles to a great extent northern Sweden and this could explain the good adaptation of the Lassinmaa seed orchard material to Swedish conditions.

\section{Genetic family variation in survival and height}

The model for the genetic evaluation assumes that, since open pollinated seeds are analysed, the material is half-sib families (not the stand and seed orchard collections). What is assumed to be half-sibs may, however, in fact be full-sibs after pollination from the same father tree, and this implies an overestimation of the heritabilities, in certain for L. sukaczewii which grows scattered 
in species mixtures. The present results did not give any clear pattern for heritabilities for survival or height growth. Individual heritabilities were generally low (0.02-0.10). The few significant estimates occurred irregularly, not allowing general conclusions (Table 7a, $b$ ). For survival, one pattern was however that $h^{2}{ }_{p+i}$ was highest in the site with the best height growth, Österbymo (Table 7a), while no clear genetic pattern was indicated for height growth (Table 7b). Although some of the heritabilities were high, few of them were significant. One probable reason for the low heritabilities is the early age at measurement. At low age, it is likely that the immediate non-genetic effects of seed weight still dominate in plant growth. It is well known that initial growth is largely dependent on the seed quality as summarized in PARKER et al. (2004), and stated for Japanese larch (Larix kaempferi) by LOGAN and POLLAND (1981) and for Scots pine by REICH et al. (1994). In this material there were large geographic and climatic differences in the locations of the seed sources and this has probably resulted in such important differences in seed ripening, seed weight, and seed quality. In Österbymo with the highest mean height these immediate seed weight effects may have decreased in relation to growth capacity, and thus resulting in the highest $h^{2}{ }_{p+i}\left(h^{2}{ }_{p+i}=\right.$ 0.12-0.76, Table 7b). Also differences in micro-stand conditions could at this early evaluation play a bigger role than at later evaluations. Another reason for low significances of heritabilities is that the design with the families kept together may have introduced a larger error variance. Furthermore, family heritabilities are based on data from families within many different provenances and there is possibility that there are differences in genetic structure within them. Separate analyses for each provenance should however lead to too few families in each estimate. The trials in the present study were planted as single tree plots to minimize the covariance between families and environment. However, the blocks were large and contained several environmental gradients. This was the case especially in Järvträsk with the whole site in a quite steep slope, thus the blocks as such were not efficient for reducing the environmental variance. The significant random row(plot) and plant(plot) effects, and reduced environmental variance indicate that the model was improved. Furthermore, in Särna, one of the blocks had generally higher mortality than the other two blocks, but excluding this block did not change the heritabilities.

The individual additive genetic coefficients of variation $\left(C V_{A}(i)\right)$ for height suggested relatively high genetic variation for L. sukaczewii and L. sibirica (Table 7a,b). The highest values were found in Särna with $C V_{A}(i)$ of $15 \%$ and $19 \%$, respectively for the two species. CoRNELIUS (1994) compiled $C V_{A}(i)$ values from 67 different studies, mostly on different pine species and found a mean value of $C V_{A}(i)$ to be $11 \%$ for height. The provenance+family genetic variation was considerably higher $\left(C V_{A(p+i)}\right.$ was $14-49 \%$ indicating that there is much to gain in a proper provenance choice. Large provenance differences are expected due to the large distribution areas. In future breeding the different provenances, regions and species should therefore be treated sepa- rately. The absence of significant family effects is most likely due to the early age, so the non-genetic effects of the seed condition and the planting process remain.

The species composition of the stands where the seed was collected for this study was described by MARTINSSON and TAKATA (2000). Poor pollen dispersal due to the high weight of larch pollen (MARTINSSON and LESINSKI, 2007) could contribute to limited gene exchange between provenances and a formation of distinct genetically differentiated provenances, especially in the scattered $L$. sukaczewii populations. The L. sibirica material in this study is from stands with higher larch content, usually $80-90 \%$, and the L. cajanderi and L. gmelinii provenances were collected from pure larch stands in central and eastern Siberia (ABAIMOV et al., 1998). This could result in more continuous genetic variation for these. The heterogeneity of the Russian larch populations is strengthened by previous research on the genetic variation in the Eurasian larch species. HAGMAN (2003) reported considerable within population variation in both Larix gmelinii and L. sibirica whereas PUTENIKHIN (2002) found relatively low intra population diversity in southern Ural populations of $L$. sukaczewii. The variability increased in northern Ural and high-mountain populations.

\section{Conclusions}

- Good initial adaptation was shown by provenances of Larix sukaczewii originating from north western Russia and provenances of $L$. gmelinii from the Russian Far East. Provenances of $L$. sibirica and $L$. cajanderi appear to be less suitable for Swedish conditions.

- The degree of continentality to which the larch material is adapted, seems to be more important for high survival and height growth than latitudinal origin. Transfer from strongly continental areas resulted in poor growth.

- A latitudinal northward transfer of Larix sukaczewii of 2-3 degrees appear to result in satisfactory survival and height growth on the harshest site, whereas southern transfer resulted in lower survival and poor growth. The continentality of the climate at provenance origin also had a significant effect for $L$. sukaczewii with more continental provenances having lower survival and height growth especially on the most northern site.

- The early age of the present progeny tests (5 years) is most likely the main reason for the low or absence of significant genetic information at the family level. The progeny tests need to be followed up at a higher age to avoid the apparent risk of erroneous conclusions based on early establishment performances.

- At present, it appears that a future breeding program for larch in Sweden should be based on selections of high performing trees within the best provenances of Larix sukaczewii and possibly of L. gmelinii.

\section{Acknowledgements}

We are grateful to TOM GÄRDS, LENA HELIN, JOEL Kelloniemi, Lidia Kovler, KURT OlsSON, HÅKAN SCHÜBERG, for help with field measurements. Thanks 
also to SusAn JEGLUM who revised the language. DAG LINDGREN and SEPPO RUOUTSALAINEN gave valuable comments on the manuscript. JAN-ERIK NILSSON, TORE ERICSSON and ROBERT NYGÅRD gave statistical advice. Financial support from Interreg and the Kempe foundation is also acknowledged.

\section{References}

Abaimov, A. P., V. M. Barzut, A. N. Berkutenko, J. Buitink, O. Martinsson, L. I. Milyutin, A. Polezhaev, V. P. Putenikhin and K. TAKatA (2002): Seed collection and seed quality of Larix spp. From Russia - Initial phase on the Russian-Scandinavian Larch Project, Eurasian J. For. Res. 4, 39-49.

Abaimov, A. P., J. A. Lesinski, O. Martinsson and L. I. MiLYUTIN (1998): Variability and ecology of Siberian larch species. Swed. Univ. Agri. Sci. (Umeå), Dep. Silviculture, Reports 43. 123 pp.

Bashalkanov, S. I., Y. M. Konstantinov, D. S. Vergitski and V. F. Kobzev (2003): Reconstruction of phylogenetic relationships of larch (Larix sukaczewii Dyl.) based on chloroplast DNA trnK intron sequences. Russian Journal of Genetics 39, 1322-1327.

Bergman, I., A. Olofsson, G. Hörnberg, O. Zackrisson and E. HeLlBerg (2004): Deglaciation and colonization: Pioneer settlements in northern Scandinavia. Journal of World Prehistory 18(2): 155-177.

Bobrov, E. G. (1972): Istoria e sistematika listvinnits [History and systematics of larch species] Izd "Nauka " Leningrad (in Russian) 95 pp.

Carswell, C., L. and E. K. Morgenstern (1995): Phenology and growth of nine larch species and hybrids tested in New Brunswick, Canada. In: ScHMIDT and McDonALD (editors): Ecology and Management of Larix Forest: A look Ahead. USDA Forest Service, Intermountain Research Station, GTR-INT-319, 50-57.

CONRAD, V. (1946): Usual formulas of continentality and their limits of validity. Transactions American Geophysical Union 27: 663-664.

CoRnElius, J. (1994): Heritabilities and additive genetic coefficients of variation in forest trees. Can. J. For. Res. 24: 372-379.

Dormling, I., A. Gustafsson and D. von Wettstein (1968): The experimental control of the life cycle in Picea abies (L.) Karst. I. Some basic experiments on the vegetative cycle. Silvae Genet. 17: 44-64.

Dylis, N.V. (1947): Siberian larch. Materials for taxonomy, geography and history. Moscow Society of Naturalists. New Ser Botan. Dep., 2. Moscow. 139 pp.

DyLIS, N.V. (1981): Listvennitsa [Larch]. Moscow: Izd. "Lesn. Promyshl". (In Russian).

EDLund, E. (1966): Den Sibiriska lärken i Norrland och Dalarna som skogsträd och industriråvara. Sveriges Skogsvårdsförbunds Tidskrift 5-6: 451-560. (in Swedish).

Eiche, V. (1966): Cold damage and plant mortality in experimental plantations with Scots pine in northern Sweden. Stud. For. Suec. 36: 1-218.

EIDMANN, H. H. and A. KLINGSTRÖM (1990): Skadegörare i skogen. LT förlag, Stockholm, 1-355.

Eriksson, G., S. Andersson, v. Eiche, J. Ifver and A. Persson (1980): Severity index and transfer effects on survival and volume production of Pinus sylvestris in northern Sweden. Stud. For. Suec., nr 156.
ERIKSSON, G., I. EkBerG and D. Clapham (2006): An introducton to forest genetics. ( $2^{\text {nd }}$ ed.). Swed. Univ. of Agric. Sci. ISBN 91-576-7190-7.

Eysteinsson, T. and B. Skúlason (1995): Adaptation of Siberian and Russian larch provenances to spring frost and cold summers Búvísindi. Icel. Agr. Sci. 9, 1995: 91-97.

Eysteinsson, T. (2002): Progeny trials of Larix sukaczewii in Iceland - 3 year results. In: Improvement of larch (Larix sp.) for better growth, stem form and wood quality. Proceedings of an International Symposium, Gap (Hautes-Alpes) - Auvergne \& Limousin, France, 16-21 September, 2002.

Eysteinsson, T., L. Karlman, A. Fries, O. Martinsson and B. Skúlason (2009): Variation in spring and autumn frost tolerance among provenances of Russian larches (Larix Mill.) Scandinavian Journal of Forest Research, Vol. 24, No. 2., pp. 100-110.

FALCONER, D. S. (1989): Introduction to Quantitative Genetics. Ed. 3. Longmans Green/John Wiley \& Sons, Harlow, Essex, UK/New York.

Gilmour, A. R., B. J. Gogel, B. R. Cullis and R. ThompSON (2006): ASReml User Guide Release 2.0. VSN International Ltd, Hemel Hempstead.

Hagman, M. (1995): Experiences with Larix species in northern Finland. Finnish Forest Research Institute Research Papers 567: 111-123.

HAGMAN, M. (2003): Genetic diversity of Eurasian boreal conifers. Acta Horticulturae (615): 177-187.

Hansson, P., J. Witzell, M. Wikström and O. Rosvall (2005): The effect of provenance on disease incidence of Gremmeniella abietina in 50-year old Pinus sylvestris. In: Stanosz, G. R. and Stanosz J. C. 2005. "Foliage, Shoot and Stem Diseases." Proceedings of the Meeting of Working Party 7.02.02 of the International Union of Forestry Research Organizations, Corvallis, Oregon, USA, June 13-19 2004. p. 61-63.

KHAtab, I. A., H. Ishiyama, N. Inomata, X-R. WANG and A. E. SzMIDT (2008): Phylogeography of Eurasian Larix species inferred from nucleotide variation in two nuclear genes. Genes \& Genet. Syst. 83, 55-66.

KJELLSTRÖM, E. and P. LIND (2009): What can multiple climate change simulations tell us about the future Swedish climate? Mistra.SWECIA Newsletter1, June 2009.

KullmanN, L. (1998): Paleoecological, biogeographical and paleoclimatological implications of early Holocene immigration of Larix sibirica into the Scandes mountains, Sweden. Global Ecology and Biogeography Letters, 5 .

LARSSON-STERN, M. (2003): Aspects of Hybrid larch (Larix $\mathrm{x}$ eurolepis Henry) as a potential tree species in southern Swedish forestry. Licentiate Thesis. Swed. Univ. Agr. Sci., Alnarp. 28 pp.

LINDGREN, D. (1994): When do temperature events take place in Sweden and Finland? Swedish University of Agricultural Sciences, Department of Forest Genetics and Plant Physiology, Report 51: 1-38 (1994).

LoGAN, K. T. and D. F. W. Polland (1981): Effect of seed weight and germination rate on the initial growth of Japanese larch. Bi-monthly Research Notes 5(5), 28-29.

Lukkarinen, A. J., S. Ruotsalainen, T. Nikkanen and H. Peltola (2009): The growth rhythm and height growth of seedlings of Siberian (Larix sibirica Ledeb.) and Dahurian (Larix gmelinii Rupr.) larch provenances in greenhouse conditions. Silva Fennica 43(1): 5-20. 
Martinsson, O. (1995): Yield of Larix sukaczewii Dyl. in northern Sweden. Stud. For. Suec., 195. 20 pp.

Martinsson, O. and B. Nilsson (1987): The impact of Cronartium flaccidum on the growth of Pinus sylvestris Scand. J. For. Res. 2(1): 349-357.

MARTinsson, O. and K. TAKATA (2000): The Russian-Scandinavian Larch project. Final report on seed collection and seed germination. Working papers 159. Dep. Of silviculture, Swedish University of Agricultural Sciences.

MARTINSSON, O. and K. TAKATA (2005): International family test of Eurasian larch species. Eurasian J. For. Res. 8-2: 97-103.

Martinsson, O. and J. A. Lesinski (2007): Siberian larch: Forestry and Timber in a Scandinavian perspective (90 pp.). Jämtland, Sweden: JiLU Jämtland County Council institute of Rural Development.

MIKOLA and VAKKARI (1995): Genotype * environment interactions in the Raivola provenance of Larix sibirica in Finland. BÚVÍSINDI, Icelandic Agriculture Science 9: $81-90$

Milyutin, L. I. and K. D. Vishnevetskaia (1995): Larch and Larch forests of Siberia. In: SCHMIDT and MCDONALD (editors): Ecology and Management of Larix Forest: A look Ahead. USDA Forest Service, Intermountain Research Station, GTR-INT-319, 50-57.

New, M., D. Lister, M. Hulme and I. MAKin (2002): A high-resolution data set of surface climate over global land areas. Climate Research 21. 25p.

Polar Research Group (2009): The Cryosphere Today website. Univ. of Illinois at Urbana-Champaign, Dept of Atmospheric Sci. http://arctic.atmos.uiuc.edu/ cryosphere/.

PARKER, W. C., T. L. Noland and A. E. Morneault (2004): Effect of seed mass on early seedling growth of five eastern white pine (Pinus strobus L.) families. Can. J. Bot. 82: 1645-1655.

Putenikhin, V. P. and O. Martinsson (1995): Present distribution of Larix sukaczewii Dyl. in Russia. Swed. Univ. Agric. Sci., Dep Silviculture, rep 38,78 pp.

Putenikhin, V. P. (2002): Phenotypic diversity, introgressive hybridization and microevolution of Larix sukaczewii Dyl. in the Urals. In: Improvement of larch (Larix sp.) for better growth, stem form and wood quali- ty. Proceedings of an International Symposium, Gap (Hautes-Alpes) - Auvergne \& Limousin, France, 16-21 September, 2002.

REHFELdT, G. E., N. D. TChebakova and L. K. BARNGARDT (1999): Efficiency of climate transfer functions: Introduction of Eurasian populations of Larix into Alberta. Canadian Journal of Forest Research 29: 1660-1668.

REICH, P. B., J. Oleksyn and M. G. TJoklker (1994): Seed mass effects on germination of diverse European Scots pine populations. Can. J. For. Res. 24: 306-320.

SCHMIDT, W. C. (1995): Around the world with Larix: an introduction. In: W. C. SchmidT and K. J. MCDonald (compilers). Ecology and Management of Larix Forests: A Look Ahead. Intermountain Research Station. General Technical Report GTR-INT-319: 521 pp.

Scнотте, G. (1917): Lärken och dess betydelse för svensk skogshushållning. [The larch and its importance in Swedish forest economy]. pp. 531-840 in Meddelanden från Statens skogsförsöksanstalt. (In Swed. with 26 page Engl. Sum.)

SHVIDENKO, A. and S. Nilsson (1994): What do we know about Siberian forests? Ambio 1994 23: 7.

SIMAK, M. (1970): Photo- and thermoperiodic responses of different larch provenances (Larix decidua Mill.). Stud. For. Suec., 86, 31pp.

SIMAK, M. (1979): Larix sukaczewii: Naturlig utbredning, biologi, ekologi och fröanskaffingsproblem [Larix sukaczewii: Natural distribution, biology, ecology and seed procurement problems]. Institutionen för skogsskötsel Rapporter 1-1979, (76 pp). Umeå, Sweden: Swedish University of Agricultural Sciences. (In Swedish with Russian and English summaries.)

STENER, L.-G. (2007): Tidig utvärdering av fyra sydsvenska forsook med olika lärkarter av olika genetiskt ursprung. Arbetsrapport från Skogforsk, nr 650, 21p. (In Swedish).

TigerstedT, P. (1993): Genetic diversity of tree populations at their arctic limits. In: J. AldEN, J. L. MASTRANTONIO and S. OEDUM (Eds.). Forsest development in cold climates. New York: Plenum press

Öyen, B. H., J.-O. SkAGe, H. NyEGREN and Å. ÖstGÅRD (2007): Russerlerk - dyrkningspotential på Vestlandet? Norskt skogbruk 53(1): 34-36. (In Norwegian). 